\title{
Economic analysis of beekeeping enterprises in Aegean Region, Turkey"
}

\author{
Mustafa Bahadır ÇEVRIMLİ ${ }^{1}$, Engin SAKARYA ${ }^{2}$ \\ ${ }^{1}$ Selçuk University, Faculty of Veterinary Medicine, Department of Livestock Economics and Management, Konya; \\ ${ }^{2}$ Ankara University, Faculty of Veterinary Medicine, Department of Animal Health Economics and Management, Ankara, Turkey.
}

Summary: The aim of this study was to determine the economic analysis of beekeeping enterprises in Aegean Region of Turkey. The material of the current study was collected through face to face interviews from the total of 73 small, medium and largescale enterprises determined by simple random sampling in Aegean region of Turkey (Aydın, Denizli, Mugla provinces). A backward regression model was developed to assess the input and output relationships in the enterprises. According to the results, the factors that affect the total profit, namely, marketing costs, sale price, unit cost, equipment and other expenses were found to be statistically significant $(\mathrm{p}<0.05)$. In the study, the lowest cost of producing honey was found to be in large-scale enterprises $(1.82 \mathrm{US} \$ / \mathrm{kg})$ and in the province of Aydin (1.64 US\$ $/ \mathrm{kg}$ ), whereas the highest cost of producing honey was found to be in small-scale enterprises (3.14 US $\$ / \mathrm{kg}$ ) and in the province of Denizli (3.79 US\$ $/ \mathrm{kg}$ ). Net profit was calculated to be 41.16 US $\$ /$ hive in small-scale, 28.75 US $\$ / \mathrm{hive}$ in medium-scale and 35.45 US\$/hive in large-scale enterprises. In conclusion, considering that the major problem of beekeeping enterprises in Aegean Region is the marketing (64.3\%) and the, study also suggested that some measures and supports actions should be put into practice including augmentation of the sale opportunities of the honey produced and the activation of structures of cooperatives so that the profitability of enterprises may be increased, and beekeeping activity may be carried out in a sustainable manner.

Keywords: Beekeeping enterprises, cost, economic analysis, honey, marketing.

\section{Türkiye'de arıcılık işletmelerinin ekonomik analizi; Ege Bölgesi örneği}

Özet: Bu araştırma Türkiye'de Ege bölgesindeki arıcılık işletmelerinin ekonomik analizinin gerçekleştirilmesi amacıyla yapılmıştır. Araştırma materyalini Ege bölgesinde (Aydın, Denizli, Muğla) tesadüfi örnekleme yöntemiyle belirlenen küçük, orta ve büyük olmak üzere üç farklı ölçekte toplam 73 adet işletmenin yüz yüze görüşme yöntemi ile elde edilen 2014-2015 yıllarına ait veriler oluşturmuştur. İşletmelerde girdi-çıktı ilişkilerinin değerlendirilmesi için backward regresyon modeli oluşturulmuş, toplam kâra etki eden unsurlardan; pazarlama masrafları, satış fiyatı, birim maliyet, ekipman giderleri ve diğer giderler istatistiksel olarak anlamlı $(\mathrm{p}<0.05)$ bulunmuştur. Araştırmada bal üretim maliyeti en düşük (1.82 US\$) büyük ölçekli işletmelerde ve iller bazında Aydın'da (1.64 US\$ $/ \mathrm{kg}$ ) bulunurken, en yüksek üretim maliyeti (3.14 US\$/kg) küçük ölçekli işletmelerde ve iller bazında Denizli'de (3.79 US\$/kg) tespit edilmiştir. Kovan başına net kâr küçük ölçekli işletmelerde 41.16 US\$, orta ölçekte 28.75 US\$, büyük ölçekte 35.45 US\$ olarak hesaplanmıştır. Sonuç olarak Ege Bölgesi'nde arıcılık işletmelerinin başlıca sorununun pazarlama olduğu $(\% 64,3)$, işletmelerde kârlılığının artması ve sürdürülebilir bir arıcılık faaliyeti için, üretilen balın perakende satış imkânlarının çoğaltılması, kooperatif yapıların etkinleştirilmesi başta olmak üzere pazarlama alanında bir takım destek ve tedbirlerin hayata geçirilmesi büyük önem arz etmektedir.

Anahtar sözcükler: Arıcılık işletmesi, bal, ekonomik analiz, maliyet, pazarlama.

\section{Introduction}

Beekeeping has some advantages, of which can be carried out in conjunction with various plant and animal production activities and without depending on land and that it requires less capital and labour. In addition, it provides socio-economic functions by increasing the level of income of the farmers that do not have plenty of lands, while also preventing migration from rural to urban areas and, creating employment for the young population in rural areas $(10,16,20)$.

Turkey ranks second following China in terms of both the number of hives and the annual amount of honey production in the world (9). Nevertheless, Turkish beekeeping sector has been facing technical and economic

\footnotetext{
* This manuscript is derived from the Ph.D. thesis of the first author. The study was presented as an oral presentation 45 ${ }^{\text {th }}$ APIMONDIA (International Apicultural Congress)
} 
problems which include the low productivity per hive, bee diseases, pests, failure to increase the export capacity, difficulties encountered by beekeeping enterprises in marketing their products, insufficient of the level of industry organization, and unexpected migratory beekeeping. In addition to the sector's own problems, competition in the globalizing world has become a key factor that the Turkish beekeeping sector needs to consider $(7,21)$.

This study aimed to calculate the unit cost of producing per $\mathrm{kg}$ of honey in different provinces and enterprises and to figure out whether there is a statistically significant difference between these costs as well as between the sale prices of honey produced in Aydin, Denizli and Mugla provinces and enterprises. Furthermore, it also attempted to identify what sort of economic problems the enterprises faces in marketing honey by assessing the input and output relationships of the enterprises.

\section{Materials and Methods}

Beekeeping enterprises were categorised as smallscale (30-150 hives), medium-scale (151-300 hives) and large-scale (301 and more hives) enterprises. Taking into account the number of population hives of enterprises that had 30 or more hives among 1,057 enterprises in Aydın, 571 enterprises in Denizli and 3,568 enterprises in Mugla, the average number of hives of each stratum on the basis of three provinces and three stratums, the number of enterprises in each stratum and their standard deviation values were calculated. In determining the sample size of the study, "Stratified Random Sampling" was employed, which included the use of Neyman allocation $\mathrm{n}=\left[\sum(\mathrm{Nh} \times \mathrm{Sh})^{2}\right] /\left[\mathrm{N}^{2} \mathrm{D}^{2}+\sum(\mathrm{Nh} \times(\mathrm{Sh}))^{2}\right]$ [1] with a margin of error of $10 \%$ and within a confidence limit of $90 \%$. First, the total sample size in each province was determined, and then they were distributed to the different stratum (17). The numbers of beekeeping enterprises included in the sample for each province and stratum are given in Table 1.

Table 1. Numbers of beekeeping enterprises in the sample by provinces and scales

Tablo 1. Örneklem kapsamındaki arıcılık işletmelerinin illere ve ölçeklere göre sayıları

\begin{tabular}{cccc}
\hline Provinces & $\begin{array}{c}\text { Number of } \\
\text { sample }\end{array}$ & Scale & $\begin{array}{c}\text { Number of } \\
\text { sample }\end{array}$ \\
\hline Aydın & 24 & Small & 30 \\
Denizli & 16 & Medium & 23 \\
Mugla & 26 & Large & 13 \\
\hline \multicolumn{5}{c}{ Total number of sample 66} \\
\hline
\end{tabular}

Table 1 demonstrates that the minimum sample size of the study is 66, which includes 24 enterprises from Aydın, 16 from Denizli and 26 from Mugla. As to the distribution of this number by scales, it includes 30 smallscale, 23 medium-scale and 13 large-scale enterprises. Together with the reserve enterprises selected for the study, 80 beekeeping enterprises were interviewed between October 2014 and May 2015, and the data of 73 reliable enterprises were taken into account. The questionnaire drawn up for this purpose was distributed to the enterprises during the visits paid, and also additional information was acquired during the visits paid at intervals. The production costs of beekeeping enterprises taken into account in the study include feeding costs, labour costs, costs of auxiliary materials used in production, marketing expenses, hive transportation costs, loan interests, other expenses, overhead costs and building/equipment costs. Operating revenues include the revenues generated from the sale of honey, whereas the revenues generated from the sale of pollen, propolis, etc. were grouped as the additional income. The data collected in the study are intended to provide information on the use of inputs and marketing.

In analysing the data, one-way analysis of variance (ANOVA) was carried out to find out whether there was a significant difference between unit costs of producing $1 \mathrm{~kg}$ of honey in different provinces and enterprise scales as well as between the sale prices of honey. In the first two hypotheses, scales (small, medium and large) are the independent variables, whereas the cost of producing $1 \mathrm{~kg}$ of honey and sale price of $1 \mathrm{~kg}$ of honey in US dollars are the dependent variables. In the third and fourth hypotheses, provinces (Aydın, Denizli, and Mugla) are the independent variables, whereas the cost of producing $1 \mathrm{~kg}$ of honey and sale price of $1 \mathrm{~kg}$ of honey in US dollars are the dependent variables. It was found that there was no difference between the groups' average unit costs and sale prices of honey among the provinces in which the enterprises were located. Tukey and adjustment Bonferroni post-hoc tests were used to determine from which scale and province the difference between the groups arose $(11,19)$.

Multiple regression analysis was conducted in an effort to functionally assess honey production in the beekeeping enterprises. The regression model was checked for the assumptions for multiple linear regression analysis, namely, normality, linearity, zero-mean error terms, homoscedasticity, and no autocorrelation and no multicollinearity between independent variables. The variables were found to be not correlated with each other at an autocorrelation factor of 0.80 and above. In the regression analysis, all independent variables were included in the model and backward regression method 
was applied $(2,11,19)$. The model used in the regression analysis is as follows:

$$
\begin{aligned}
Y= & b_{0}+b_{1} X_{1}+b_{2} X_{2}+b_{3} X_{3}+b_{4} X_{4}+b_{5} X_{5}+b_{6} X_{6}+b_{7} X_{7} \\
& +b_{8} X_{8}+b_{9} X_{9}+b_{10} X_{10}+b_{11} X_{11}+\varepsilon
\end{aligned}
$$

In the model developed for this study, the dependent variable $(\mathrm{Y})$ denotes the total profit generated by beekeeping enterprises from the sale of honey in US dollars.

$\mathrm{Y}=$ Enterprise's profit in US dollars;

The independent variables included in the model are as follows:

$\mathrm{X}_{1}=$ Cost of feeding bees; feeding costs of bees in US dollars, $\mathrm{X}_{2}=$ Labour costs; total cost of family and external labour in US dollars, $\mathrm{X}_{3}=$ Cost of auxiliary materials; cost of materials procured annually in US dollars, $\mathrm{X}_{4}=$ Marketing costs; packaging and marketing costs of honey in US dollars, $\mathrm{X}_{5}=$ Transportation costs; costs incurred for transportation of hives and leasing of land in US dollars, $\mathrm{X}_{6}=$ Other expenses; total cost of loan interest, veterinary health expenses, hive and vehicle insurance, water and lighting in the hive site, and shuttle for checking the hives in US dollars, $\mathrm{X}_{7}=$ Equipment cost; Maintenance, repair and depreciation costs of hives, machinery, equipment and tools used in beekeeping in US dollars, $\mathrm{X}_{8}=$ Sale price; sale price of $1 \mathrm{~kg}$ of honey in US dollars, $\mathrm{X}_{9}=$ Unit cost of production; production cost of $1 \mathrm{~kg}$ of honey in US dollars, $\mathrm{X}_{10}=$ Scale $_{1}$ (Small vs. Large), $\mathrm{X}_{11}=$ Scale $_{2}$ (Medium vs. Large), $\varepsilon=$ Error term.

Excluding the scale, the independent variables in the model are quantitative. The scale variables $X_{10}$ and $X_{11}$ are qualitative and have three categories (small, medium and large). Since the qualitative independent variables with more than one category need to be included in the model as dummy variables, 2 dummy variables were included in the regression analysis for the scale variable with three categories (11). As some of the cost items such as loan interest and veterinary health expenses are zero for some enterprises and their percentage in the total costs of the enterprises is very low, than they were named as other expenses and considered together in the regression analysis.

In regression analysis, a high correlation between the dependent (total profit) and independent variables is an undesirable condition. If the coefficient of correlation between independent variables is 0.80 or above, this is considered an indication of the multicollinearity problem. Another criterion for the presence of autocorrelation in the model is the requirement that the Durbin-Watson statistic should be between 1.5 and $2.5(5,6)$. SPSS 18.0 was used to conduct the statistical analyses.

\section{Results}

Using the cost items, total honey production records and additional income information provided by the enterprises, the cost of producing $1 \mathrm{~kg}$ of honey in the beekeeping enterprises was calculated for each scale and province. Using the sale price of $1 \mathrm{~kg}$ of honey, net profit per hive was calculated for each scale and province. These figures are given in Table 2.

Table 2 shows that the lowest cost of producing $1 \mathrm{~kg}$ of honey was found to be in large-scale enterprises as 1.82 US\$ and in Aydin as 1.64 US\$. The highest cost of producing $1 \mathrm{~kg}$ of honey was found to be in small-scale enterprises as 3.14 US\$ and in Denizli as 3.79 US\$. As to the sale prices, the highest sale price of $1 \mathrm{~kg}$ of honey is in small-scale enterprises as 6.10 US\$ and in Denizli as 6.47 US\$. Net profit per hive was found to be the highest in small-scale enterprises as 41.16 US\$ and in Aydin as 47.53 US\$. The average cost of production, sale price and net profit per hive of all enterprises within the scope of the study are 2.49 US\$, 4.93 US\$ and 35.64 US\$, respectively. The lowest net profit per hive was found to be in Mugla as 26.49 US\$.

Variance analyses conducted and statistically significant differences are given in Table 3 .

Table 3 shows that there is no statistically significant difference between the average unit costs of the groups of enterprise scales $(\mathrm{p}>0.05)$.

Table 2. Honey production costs, sale price of honey and net profit per hive of beekeeping enterprises by scales and provinces Tablo 2. Arıcılık işletmelerinde ölçekler ve iller itibariyle ortalama bal üretim maliyetleri, satış fiyatları ve kovan başına net kâr miktarları

\begin{tabular}{lcccc}
\hline Criterion & $\begin{array}{c}\text { Number of } \\
\text { enterprises }\end{array}$ & $\begin{array}{c}\text { Honey cost } \\
\left(\mathrm{X} \pm \mathbf{S}_{\overline{\mathbf{X}}}\right)(\mathrm{US} \$ / \mathrm{kg})\end{array}$ & $\begin{array}{c}\text { Honey sale price } \\
\left(\mathrm{X} \pm \mathbf{S}_{\overline{\mathbf{X}}}\right)(\mathrm{US} \$ / \mathrm{kg})\end{array}$ & $\begin{array}{c}\text { Net profit per hive } \\
(\mathrm{US} \$)\end{array}$ \\
\hline Small scale & 33 & $3.14 \pm 1.20$ & $6.10 \pm 1.21$ & 41.16 \\
Medium scale & 26 & $2.01 \pm 0.74$ & $4.00 \pm 0.73$ & 28.75 \\
Large scale & 14 & $1.82 \pm 1.17$ & $3.79 \pm 1.60$ & 35.45 \\
Aydin & 24 & $1.64 \pm 1.52$ & $5.07 \pm 1.07$ & 47.53 \\
Denizli & 19 & $3.79 \pm 1.18$ & $6.47 \pm 1.78$ & 35.09 \\
Mugla & 30 & $2.34 \pm 0.49$ & $3.82 \pm 0.89$ & 26.49 \\
Total & 73 & $2.49 \pm 0.66$ & $4.93 \pm 0.75$ & 35.64 \\
\hline
\end{tabular}


Table 3. Findings from variance analyses

Tablo 3. Varyans analizlerine ilişkin bulgular

\begin{tabular}{cccccc}
\hline Scales & Small & Medium & Large & F & $\mathrm{p}$ \\
Unit cost US $\$$ & 3.14 & 2.01 & 1.82 & 3.121 & 0.0502 \\
Sale price US\$ & $6.10^{\mathrm{a}}$ & $4.00^{\mathrm{b}}$ & $3.79^{\mathrm{b}}$ & 9.234 & $0.0002^{* * *}$ \\
\hline Provinces & Aydın & Denizli & Mugla & $\mathrm{F}$ & $\mathrm{p}$ \\
Unit cost US\$ & $1.64^{\mathrm{b}}$ & $3.79^{\mathrm{a}}$ & $2.34^{\mathrm{b}}$ & 6.579 & $0.002^{* *}$ \\
Sale price US\$ & $5.07^{\mathrm{a}} \mathrm{b}$ & $6.47^{\mathrm{a}}$ & $3.82^{\mathrm{b}}$ & 8.868 & $0.0003^{* * *}$ \\
\hline
\end{tabular}

a,b: Values that bear different letters in the same row are statistically different.

$*: \mathrm{p}<0.05, * * \mathrm{p}<0.01 * * * \mathrm{p}<0.001$

Table 4. Regression coefficients of the model

Tablo 4. Regresyon modeline ilişkin katsayılar

\begin{tabular}{lcccccc}
\hline Parameters & \multicolumn{3}{c}{ Multiple linear regression model } & \multicolumn{3}{c}{ Collinearity statistics } \\
\cline { 2 - 7 } Constant & $\beta$ & Std. Error & $\mathrm{t}$ & $\mathrm{p}$ & Tolerance & VIF \\
Marketing & 7609.922 & 5658.993 & 1.345 & 0.183 & - & - \\
Other Expenses & 24.711 & 3.063 & 8.067 & 0.001 & 0.596 & 1.677 \\
Equipment & -2.635 & 0.891 & -2.957 & 0.004 & 0.388 & 2.576 \\
Sale Price & 2.510 & 0.833 & 3.015 & 0.004 & 0.347 & 2.881 \\
Unit Cost & 1207.763 & 271.472 & 4.449 & 0.001 & 0.689 & 1.451 \\
\hline & -1463.276 & 306.914 & -4.768 & 0.001 & 0.697 & 1.435 \\
\hline \multicolumn{7}{c}{$\mathrm{R}^{2}$} \\
\hline
\end{tabular}

Table 5. Problems encountered by beekeeping enterprises in marketing their products and percentages of encountering Tablo 5. Arıcılık işletmelerinin pazarlamada karşılaştıkları sorunlar ve karşılaşma oranları

\begin{tabular}{|c|c|c|}
\hline $\begin{array}{c}\text { The name of problems encountered by } \\
\text { marketing }\end{array}$ & $\begin{array}{c}\text { The number of enterprises encountered } \\
\text { the problem }\end{array}$ & $\begin{array}{l}\text { The percentage of enterprises } \\
\text { encountered the problem }(\%)\end{array}$ \\
\hline Low selling price & 40 & 54.8 \\
\hline Monopoly marketing structure & 28 & 38.3 \\
\hline Insufficient cooperation and associations & 23 & 31.5 \\
\hline Lack of quality-price relationship in Honey & 17 & 23.2 \\
\hline $\begin{array}{l}\text { Fake and smuggled honey in the market } \\
\text { results in unfair competition }\end{array}$ & 15 & 20.5 \\
\hline Glucose problem in honey & 7 & 9.5 \\
\hline Residues problem in honey & 2 & 2.7 \\
\hline Do not have any problem in marketing & 16 & 21.9 \\
\hline
\end{tabular}

The differences between the average sale prices of honey of the groups of enterprise scales were found to be statistically significant $(\mathrm{p}<0.001)$. The average sale price of honey among small-scale enterprises was found to be higher than the average sale price of honey among medium- and large-scale enterprises.

The differences between the average production costs in the provinces were found to be statistically significant $(p<0.01)$. The lowest and highest unit cost of producing $1 \mathrm{~kg}$ of honey are in Aydin and Denizli, respectively. Production costs were found to be similar in Aydin and Mugla.
The average sale prices of honey of the groups of provinces were tested for a difference, and the sale price differences were found to be statistically significant $(p<0.001)$. Based on the result, the sale prices were found to be higher than that in other provinces. The sale price difference in Aydin was found to be not statistically significant $(\mathrm{p}>0.05)$.

In the regression analysis conducted, the cost items which consists the total cost and the independent variables named scales were all included in the analysis, and each independent variable that contributed to the model the least and was not statistically significant was excluded 
from the model in six steps, leaving the model with five independent variables that were important for explaining the total profit. The $\mathrm{R}^{2}$ value, $\mathrm{t}$ statistics of independent variables and the regression coefficients derived from the result and findings of the analysis on the model developed with these independent variables are given in Table 4.

Table 4 shows that the adjusted coefficient of determination $\left(\mathrm{R}^{2}\right)$ of this model is 0.728 . This means that $72.8 \%$ of the change in the dependent variable is explained by the independent variables included in the model. The Durbin-Watson statistic, which is used to ascertain whether there is autocorrelation in the model, is 1.969 , indicating no autocorrelation in the model. The explanatory variables in the model were found to be statistically significant. Therefore, the model developed is as follows:

$$
\begin{aligned}
" \mathrm{Y}= & 7609.922+24.711 \mathrm{X}_{4}-2.635 \mathrm{X}_{6}+2.510 \mathrm{X}_{7}+ \\
& 1207.763 \mathrm{X}_{8}-1463.276 \mathrm{X}_{9}+\varepsilon "
\end{aligned}
$$

The analysis revealed that for each additional 1 US\$ incurred for "marketing $\left(\mathrm{X}_{4}\right)$ ", the total profit increases by 24.711 US\$; for each additional 1 US\$ incurred for "other expenses $\left(\mathrm{X}_{6}\right)$ ", the total profit decreases by 2.635 US\$; and for each additional 1 US\$ incurred for "equipment $\left(\mathrm{X}_{7}\right)$ " used in beekeeping, the total profit increases by 2.51 US\$. For each 1 US\$ increase in the "sale price $\left(\mathrm{X}_{8}\right)$ ", which is one of the independent variables, the total profit increases by 1207.763 US\$, and for each 1 US\$ increase in the "unit cost $\left(\mathrm{X}_{9}\right)$ ", the total profit decreases by 1463.276 US\$. Accordingly, the enterprises need to focus on marketing activities to increase their profitability. They need to enhance their retail sale opportunities to raise their sale prices and can reduce their unit costs by managing their operations successfully.

The $49.4 \%$ of beekeeping enterprises sell their honey to wholesalers/traders, $42.5 \%$ by retail, $6.8 \%$ to honey processing companies and $1.3 \%$ to a cooperative. While the average sale price is $6.63 \mathrm{US} \$ / \mathrm{kg}$ when enterprises market their honey by retail in small packages up to $5 \mathrm{~kg}$, the price falls to $3.87 \mathrm{US} \$ / \mathrm{kg}$ when sold by retail in $27-\mathrm{kg}$ large tins and to $2.79 \mathrm{US} \$ / \mathrm{kg}$ when sold wholesale. Attempts were made to find out in detail the problems encountered by the enterprises in marketing their honey. It was found that a significant portion of the enterprises faces more than one problem. While 47 of them $(64.3 \%)$ report that they encounter more than one problem in marketing their products, 10 enterprises $(13.8 \%)$ report that they face one problem and 16 enterprises $(21.9 \%)$ report that they do not have any problem in marketing their products. It was found that the enterprises that did not encounter any problem marketed their products by retail without depending on any wholesaler or company.
The findings on the problems encountered in marketing are given in Table 5 along with the name of the problems and the percentage of encounters.

Table 5 shows that the problem that enterprises encounter the most in marketing their products is that they cannot sell their products at a price they are worth with a percentage of $54.8 \%$. The second most encountered problem $(38.3 \%)$ is that wholesalers and companies follow a monopolistic purchase price policy, and the third most encountered problem $(31.5 \%)$ is that cooperatives and provincial associations are not effective in honey marketing channels. The percentage of enterprises reporting that fake and smuggled honey in the market results in unfair competition and this is a major problem for the marketing of their products is $20.5 \%$. $9.5 \%$ of the enterprises are having problems due to the glucose in their honey and $2.7 \%$ of the enterprises are having problems due to the residues in their honey.

\section{Discussion and Conclusion}

The reason why the unit cost of production is the lowest in Aydin is associated with the fact that the production and sale of by-products such as pollen, propolis, etc. are higher than those in the other provinces. The unit cost of production is the highest in Denizli and the difference was found to be statistically significant $(\mathrm{p}<0.01)$. This resulted from the enterprises in Denizli do not have high amount in terms of the honey production and sale of by product and that the number of points to which migratory beekeepers go is less than that in the other provinces. As the scale of the enterprise increases, the unit cost decreases, and this can be accounted for by increasing returns to scale in terms of production costs.

Similar findings were obtained from two studies conducted in Adana, Turkey and Bosnia and Herzegovina. The cost of $1 \mathrm{~kg}$ of honey in Adana is 6.7 TRY (3.99 US\$) in small-scale enterprises, 5.3 TRY (3.15 US\$) in medium-scale enterprises and 4.7 TRY (2.80 US\$) in large-scale enterprises (12). In a similar study conducted in Bosnia and Herzegovina, the cost of $1 \mathrm{~kg}$ of honey was found to be $€ 1.71$ for an enterprise with 100 hives and $€ 1.51$ for an enterprise with 300 hives (3). Based on these results, it is understood that beekeeping enterprises can reduce their production costs if they focus more on a production of by product such as pollen, propolis, etc., which have quite high sale prices, keep track of nectar flows in migratory beekeeping and increase their scale.

In a study in which the unit cost of producing $1 \mathrm{~kg}$ of honey is calculated, the unit cost is reported to be 2.67 TRY (2.00 US\$) in Izmir, 2.19 TRY (1.63 US\$) in Mugla and 2.29 TRY (1.70 US\$) in average (15). In another study conducted throughout Turkey (7), the cost of producing 1 $\mathrm{kg}$ of honey was calculated to be 6.96 TRY (2.56 US\$) which is close to $2.49 \mathrm{US} \$ / \mathrm{kg}$ calculated in this study. In 
a study conducted in Albania, the cost of producing $1 \mathrm{~kg}$ of honey is reported to be 0.6-1.5 US\$ (4).

In a study conducted in Izmir and Mugla, it is reported that $75 \%$ of the extracted honey is marketed to wholesalers/traders and $6.67 \%$ of it is marketed by retail (15). In another study conducted in the Aegean Region (13), $84 \%$ of the honey produced is reported to be marketed by wholesalers/traders. The percentage of sales to wholesalers/traders in this study, which is $49.4 \%$, is lower than that in previous studies, and the percentage of retail sales, which is $42.5 \%$, is higher than that in previous studies. It is clear that the percentage of retail sales in the Aegean Region and its provinces has an increasing trend. It was found that the producer's province of Adana in Turkey sells their products to wholesalers/traders (52.9\%), cooperatives $(29.42 \%)$ and processing companies $(7.35 \%)$ (12). It is reported that $62.4 \%$ of the extracted honey Ordu province in Turkey is sold to wholesalers/traders and $35.3 \%$ by retail (14). In another study conducted throughout Turkey (7), the percentage of wholesale is reported to be $76 \%$. The findings from studies conducted in different parts of Turkey indicate that the percentage of sales to wholesalers/traders is $50 \%$ and above.

Considering the studies on the sale prices of honey in Turkey, the average sale price of $1 \mathrm{~kg}$ of extracted honey was calculated to be 4.92 TRY in Adana (2.93 US\$) and 13.6 TRY (5.00 US\$) in average in Turkey, which is close to 4.93 US $\$$ found in this study $(7,12)$. In the scope of the research, average sales price of honey in small scale enterprises was found to be higher than medium and largescale enterprises. For this reason, small-scale enterprises may be able to market their honey in small retail packages in local markets and through personal connections.

Medium and large-scale enterprises, which make more mass production, sell wholesale in large packages ( $27 \mathrm{~kg}$ box) in the oligopolistic market conditions. Due to the oligopolistic conditions of marketing, the sales prices of medium and large-scale enterprises are falling, which is also seen in the amount of profit per hive.

In a study carried out in Croatia, $59.12 \%$ of the beekeeping enterprises are reported to be selling their products by retail, $33.96 \%$ both wholesale and retail and only $6.92 \%$ wholesale (1). In the province of Tekirdağ in Turkey, producers are reported to prefer selling their products by retail $(85 \%)$, to wholesalers/traders $(11 \%)$, to processing companies $(2 \%)$ and to the association (1\%), but $70 \%$ of the producers are reported to have difficulties in marketing their products (18). In a study conducted province of Van in Turkey, it is reported that migratory beekeepers sell $26.67 \%$ of their honey by retail and regular beekeepers sell $88.23 \%$ of their products by retail, and that as the amount of production increases, the enterprises dealing with migratory beekeeping are having more difficulties in marketing their products (8). According to this study and the previous studies conducted in Turkey, it is obvious that producers predominantly market their honey wholesale. Since the honey marketing channels in Turkey are not effective from the viewpoint of producers, their marketing preferences necessarily tend to shift from retail to wholesale as the amount of production grows. This is in line with the results of other studies suggesting that as the scale of enterprises increases, they shift to wholesale and therefore, their profitability decreases. A low price of honey, which is the major problem of beekeeping enterprises selling their products wholesale, and the marketing problem, which is reported to be the primary problem of honey producers in a study conducted in Turkey (7), is in line with the results of this study.

To conclude, the problems experienced by beekeeping enterprises in marketing their products directly affect their profitability and indirectly affect the growth and development of the sector. Beekeeping enterprises in Turkey are facing oligopolistic market conditions. Despite the presence of numerous and unorganized beekeeping enterprises, there are a limited number of wholesalers and intermediary firms purchasing honey, which agree on the price of honey or exhibit similar behaviour and follow similar policies. Unless beekeeping enterprises enhance their level of the organization in the market, it seems difficult to reach a powerful position in which they market their products at reasonable prices. Therefore, the lack of effective marketing organization by beekeeping enterprises is a significant problem that should be addressed from the viewpoint of the sector. In addition, although the unit costs of large-scale enterprises are lower, small-scale enterprises facing higher unit costs have higher profitability, and it does not seem possible for beekeeping enterprises to enhance their production scale and level of organization under the current market/marketing conditions. In order to increase the scale of enterprises is necessary to solved the problems in marketing structure. To overcome the vicious circle of the Turkish beekeeping, the marketing problems experienced by beekeeping enterprises, particularly the low level of wholesale prices, should be resolved. In the case that the marketing problems are resolved, beekeeping will be more profitable, encouraging young and dynamic producers to enter the sector, which will result in the growth of enterprise scales and the desired level of increase in the amount of honey production in Turkey. To resolve the marketing problem, the cooperatives should be rendered more effective, the existing beekeeping associations should be provided with more opportunities for marketing, and the government should implement policies aimed at dealing with the technical, economic and financial challenges in this field. The sustainability of beekeeping and honey production seems to be highly associated with this. 


\section{Acknowledgments}

We would like to thank The Turkish Association of Beekeepers (TAB) for their kindly help in field studies and coordination with the beekeeping enterprises.

\section{References}

1. Barlović N, Kezić J, Osmanagić BN, et al. (2009): Economic efficiency of beekeeping in Croatia. Agric Conspec Sci, 74, 51-54.

2. Box George EP, Jenkins GM, Reinse GC (1994): Time Series Analysis: Forecasting and Control. Upper Saddle River, NJ: Prentice-Hall

3. Cejvanovic F, Grgic Z, Maksimovic A, et al. (2011): Assumptions of economic model for sustainable productions of beekeeping in the Bosnia and Hercegovina. Journal of Agricultural Science and Technology, 5, 481-485.

4. Dedej S, Delaplane KS, Gocaj E (2015): A technical and economic evaluation of beekeeping in Albania. Bee World, 81, 87-97.

5. Durbin J, Watson GS (1950): Testing for serial correlation in least squares regression I. Biometrika, 37, 409-428.

6. Durbin J, Watson GS (1951): Testing for serial correlation in least squares regression, II. Biometrika, 38, 159-179.

7. Emir M (2015): Türkiye'de arıcıların sosyo-ekonomik yapısı ve üretim etkinliği. Ondokuz Mayıs Üniversitesi Fen Bilimleri Enstitüsü, Doktora Tezi, Samsun, Türkiye.

8. Erkan C, Aşsın Y (2001): Van İli Bahçesaray İlçesinde Arıcılı̆̆ı Yapısı ve Arıcılık Faaliyetleri. YYU J Agr Sci, 11, 19-28.

9. FAOSTAT (2017): Food and Agriculture Organization of the United Nations Statistics Division. Beekeping Statictics. Available at http://faostat3.fao.org/download/Q/*/E. (Accessed September 15, 2017)

10. Fıratlı Ç, Karacaoğlu M, Gençer H, et al. (2005): Türkiye Arıcılı̆̆ına İlişkin Değerlendirmeler ve Öneriler. 743-752. In: Türkiye Ziraat Mühendisliği VI. Teknik Kongresi Bildiri Kitab1, Ankara, Türkiye.

11. Kalaycı Ş (2014): SPSS Uygulamalı Çok Değiş̧kenli Istatistik Teknikleri. 131-266, Asil Yayınevi, Ankara.
12. Ören MN, Alemdar T, Parlakay O, et al. (2011): Adana Ilinde Arlcılık Faaliyetinin Ekonomik Analizi. Ankara: Tarımsal Ekonomi Araştırma Enstitüsü (TEAE) No: 178.

13. Özbilgin N, Alataş İ, Balkan C, et al. (1999): Ege Bölgesi Arıcılık Faaliyetlerinin Teknik ve Ekonomik Başlıca Karakteristiklerinin Belirlenmesi. Anadolu, 9, 149-170.

14. Öztürk G (2013): Ordu ili arıcılık sektörünün ekonomik yapısı üzerine bir araştırma. Atatürk Üniversitesi Fen Bilimleri Enstitüsü, Yüksek Lisans Tezi, Erzurum, Türkiye.

15. Saner G, Engindeniz S, Tolon B, et al. (2004): The economic analysis of beekeeping enterprise in sustainable development: a case study of Turkey. Apiacta, 38, 342-351.

16. Sarı̈zkan S, İnci A, Yıldırım A, et al. (2009): Beekeeping in Cappadocia Region. J Fac Vet Med Univ Erciyes, 6, 143155.

17. Shahrokh Esfahani M, Dougherty ER (2014): Effect of separate sampling on classification accuracy. Bioinformatics, 30, 242-250.

18. Soysal Mí, Gürcan EK (2005): Tekirdă̆ İli Arl Yetiştiriciliği Üzerine Bir Araştırma. Tekirdağ Ziraat Fakültesi Dergisi, 2, 161-165.

19. SPSS Inc (2009): SPSS for Windows Release 18.0. Chicago, USA.

20. Yeninar H, Akyol E, Şahinler N (2010): The effects of hive types (shield and sword) on wintering ability, survival rates and strength of honeybee colonies (A. mellifera L.) in spring season. Trop Anim Health Prod, 42, 425-429.

21. Zilberman D, Barel S (2010): The Importance of Food Safety Regulations in International Honey Exports. 54. In: IV. International Marmara Beekeeping Congress Book, Çanakkale, Turkey.

Geliş tarihi: 15.03.2018 / Kabul tarihi: 14.07.2018

Address for correspondence:

Assist. Prof. Dr. Mustafa Bahadır ÇEVRIMLI

Selçuk University, Faculty of Veterinary Medicine,

Department of Livestock Economics and Management,

Ardiçli, Selçuklu, Konya, Turkey

e-mail: bahadir.cevrimli@gmail.com 